\title{
Determination of the Effect of Iranian lavandula on Tremor in the Patients with Multiple Sclerosis: A Randomized Controlled Trial
}

Nastaran Majdinasab ${ }^{1}$, Forogh Namjoyan ${ }^{2}$, Golakeh Karimi ${ }^{3}$, Mohammad Mehravar ${ }^{4}$, Yadolah zarezadeh $^{5}$, Nasrin Abdi ${ }^{6}$, Reza Bekhradi $^{7}$

1. Professor, Neurology Department, Musculoskeletal Rehabilitation Research Center, Ahvaz Jundishapur University of Medical sciences. Ahvaz, Iran . ORCID ID: 0000-0001-5163-7210.

2. Assistant professor, Marine pharmaceutical Research Center, Ahvaz Jundishapur University of Medical Sciences. Ahvaz, Iran. ORCID ID: 0000-0002-3171-479X.

3. Neurologist, Kurdistan University of Medical Sciences. Sanandaj, Iran. ORCID ID: 0000-0001-6872-5778.

4. Instructor, Department of Physiotherapy, School of Rehabilitation Sciences, Musculoskeletal Rehabilitation Research Center, Ahvaz Jundishapur University of Medical Sciences, Ahvaz, Iran. ORCID ID: 0000-0001-8834-6521.

5. Associate Professor, Social Determinants of Health Research Center, Research Institute for Health Development, Kurdistan University of Medical Sciences, Sanandaj, Iran. ORCID ID: 0000-0001-9311-0038.

6. Assistant Professor, Social Determinants of Health Research Center, Research Institute for Health development, Kurdistan University of Medical Sciences, Sanandaj, Iran., (Corresponding Author) Tel: 087-33664658, Email:Abdi_nasrin@yahoo.com. ORCID ID: 0000-0003-4783-6019.

7. Barij Medicinal plants Research Center, Kashan, Iran. ORCID ID: 0000-0002-3000-6548.

\section{ABSTRACT}

Background and Aim: Tremor is one of the most debilitating common symptoms in the patients with multiple sclerosis (MS). Tremor can reduce patients' life quality and limit their daily activities. Considering the beneficial effects of lavandula on several neurologic disorders which have been confirmed in many studies, we decided to evaluate the effects of Iranian lavandula on tremor in MS patients.

Materials and Methods: This was a randomized double-blind clinical trial which included 30 patients with MS in Khuzestan Province from April 2017 to December 2018. The patients were divided randomly into intervention and control groups. Using goal positioning system (individual's hands), all the movements of hands and fingers were investigated during rest, posture 1, posture 2 and movement toward a specific target (kinetic) in the zero, 4th, and 8th weeks. Data collection tools were a questionnaire on tremor extracted from MDS_UPDRS questionnaire which is a comprehensive self-assessment questionnaire, a specific form of assessing EDSS, and a motion capture system. Data were converted into quantitative data by Matlab software and then analyzed.

Results: The Wilcoxon test demonstrated a significant difference among the three variables of POSTURE1, POSTURE 2, and kinetic in the group receiving the drug $(\mathrm{P}<0.05)$. There has been no significant difference between the mean values for the rest position in the eighth week and before the treatment $(\mathrm{p}=0.063)$. In the placebo group, we detected a significant difference in the kinetic variable $(\mathrm{p}<0.05)$. Considering the POSTURE1 variable, the intensity of tremor after 8 weeks reduced more in the group receiving the drug than in the placebo group. No significant difference was detected among the other variables in regard to the reduction of the tremor intensity.

Conclusion: Data Analysis in the present study demonstrated that Iranian lavandula extract with the minimum dosage of 80 milligrams is effective in reducing the tremor in patients with MS and can be used alone or as an adjunct drug.

Keywords: Lavandula, Tremor, Multiple Sclerosis

Received: July 15, 2019 Accepted: March 4, 2020

How to cite the article: Nastaran Majdinasab, Forogh Namjoyan, Golakeh Karimi, Mohammad Mehravar, Nasrin Abdi, Yadolah zarezadeh, Reza Bekhradi. Determinaion of the effect of Iranian lavandula on tremor in the patients with multiple sclerosis: A randomized controlled trial.SJKU. 2020;25(5):37-51.

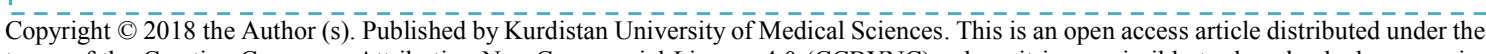
terms of the Creative Commons Attribution-Non Commercial License 4.0 (CCBYNC), where it is permissible to download, share, remix, transform, and buildup the work provided it is properly cited. The work cannot be used commercially without permission from the journal 


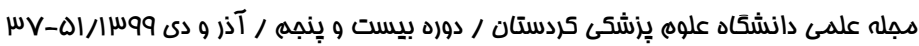

\section{تعيين تاثير كياه اسطوخودوس اير انى بر ترمور در بيمار ان مالتيِل اسكلروزيس: كار آزمايى

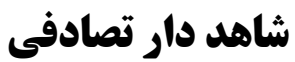

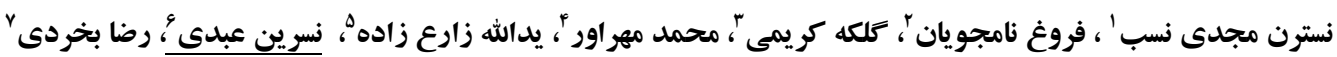

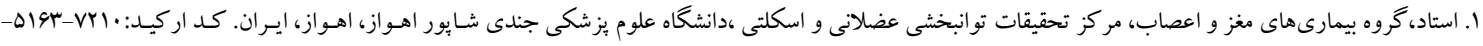

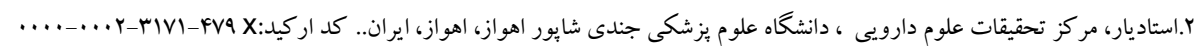

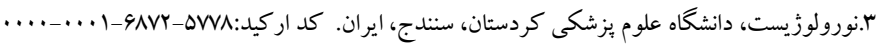

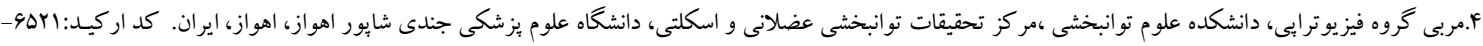
N.......-MMrF

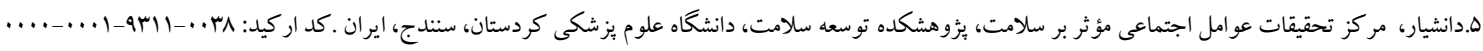

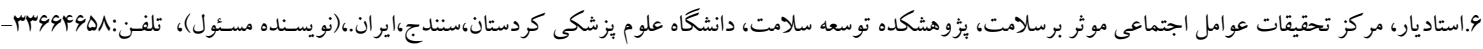

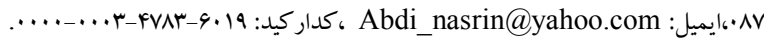

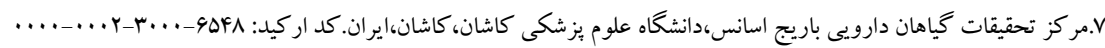
جكيده زمينه و هدف: ترمور يكى از علائم شايع ناتوان كننده دربيمارى مالتييل اسكلروزيس (MS) است كه ميتو انــ كيفيت زنـدگى را

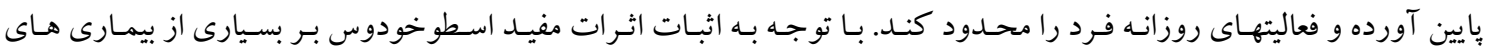

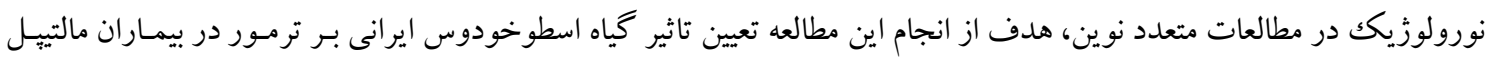
اسكلروزيس است. مواد و روشها:اين مطالعه يكك كار آزمايى بالينى تصادفى شده دوسو كور است كه بر روى •r نفـر ازبيمـاران مبتلا بـه مالتيبل

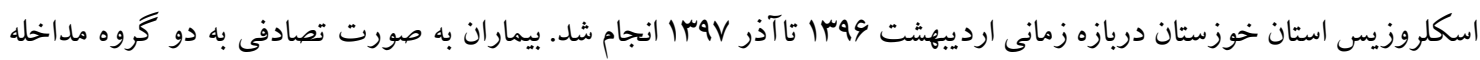
و كنترل تقسيم شدند.

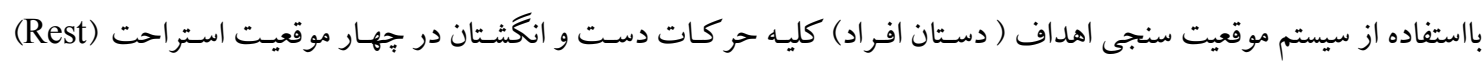

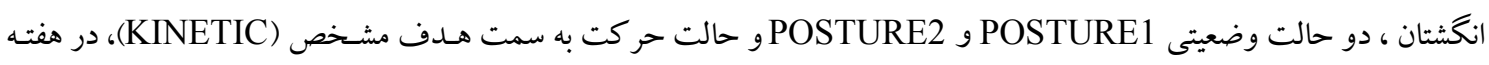

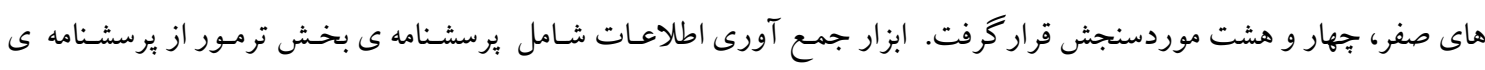

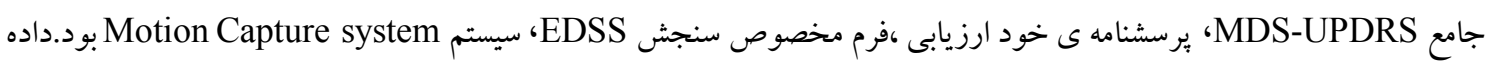
ها توسط نرم افزار MatLab به صورت كمى در آمده و آناليز شدند.

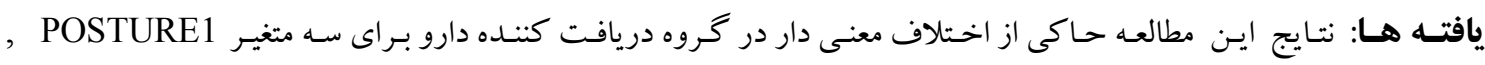

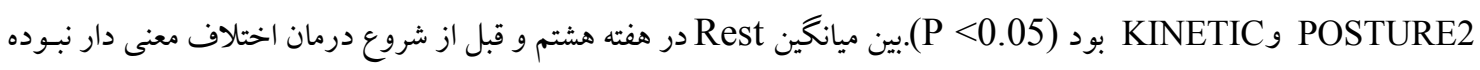

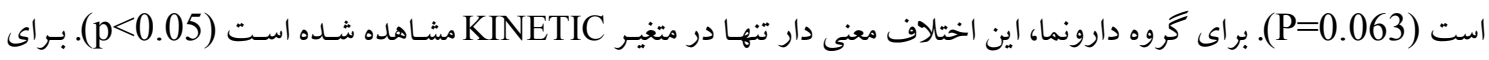

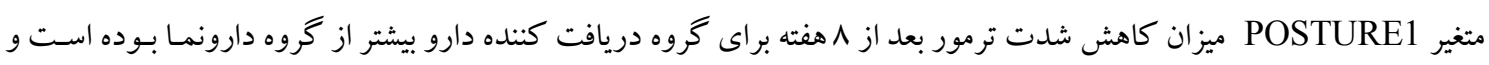

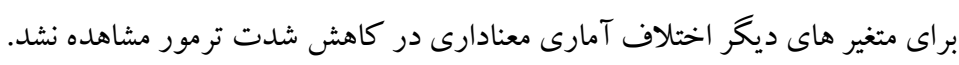

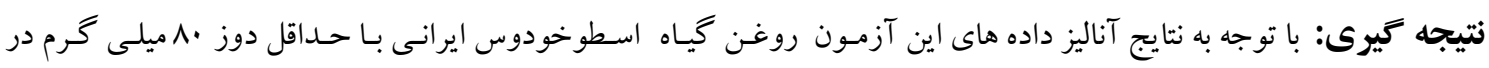

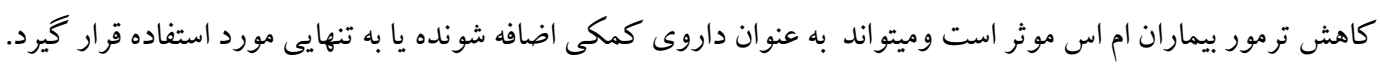
وازكان كليدى: اسطوخودوس، ترمور، مالتييل اسكلروزيس

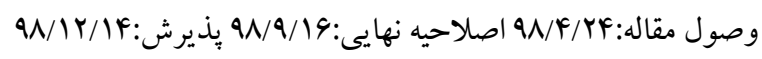


كلو تتتامايد، باكلوفن اينتراتكال و يرويرانولول است(1). البته

بايد توجه داشت كه به علت نياز بـه دوز بـالاى ايـن داروهـا جهت كنترل ترمور و در نتيجه عوارض جانبى ناشى از آن و نيز عدم موفقيت بارز اين داروها، بسيارى از بيماران مصرف داروهـا را رهـا مـى كنتـــدر كـل تـــابير درمـانى متاسـفانه موفقيت جشمخيرى در درمـان ايـن عارضـه نداشـته انـــ (F). طب جايخزين يا طب مكمل شامل انواع روشهاى درمانى

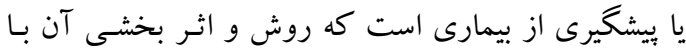
طب مرسوم يا بيولوزيك متفاوت است. در طب جايكزين

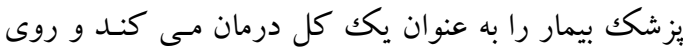

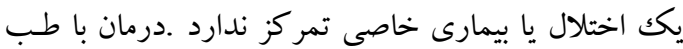
جايكزين روز بـه روز مقبوليـت بيشترى بيـدا مسى كند و

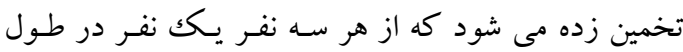
عمر خـود از اين درمانها بـراى بيماريهاى شـايعى نظير مشكلات كمر، سردرد، اضطراب و افسردگى استفاده كند

استفاده از طب مكمـل و جـايگزين در بيماريهاى مـزمن

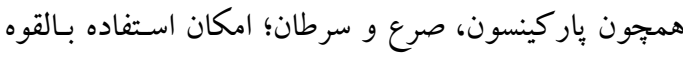

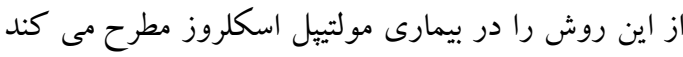

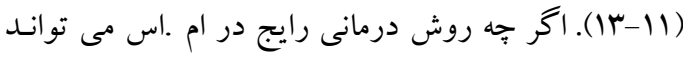
در كاهش دفعـات عود، شـدت بيمـارى و نيز كاهش

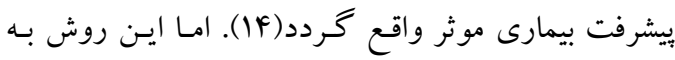

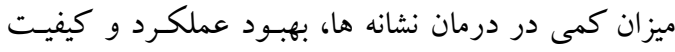

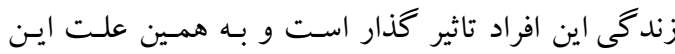
بيماران معمولا در جستجوى راههاى مختلفى براى درمان خودبر مى آيند(ها). مطالعات نشان مى دهند كهد تـا

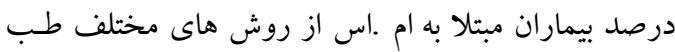

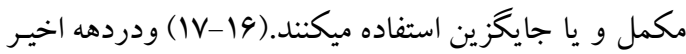

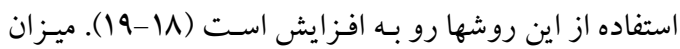

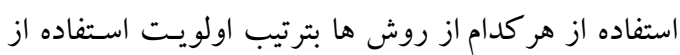

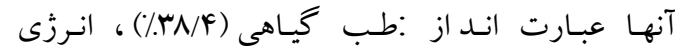

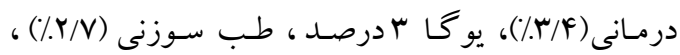

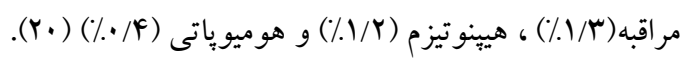

مقدمه مالتيـل اسكلروزيس Multiple Sclerosis ) شـايعترين بيماريست كه توسط يروسه ى التهابى - ميلين زدا ايجـاد ميشود ـ اين بيمارى سيستم عصبى مر كزى رادر گير ميكند. ام اس يكى از علل اصلى منتهى بـه نـاتوانى در بـالغين جـوان

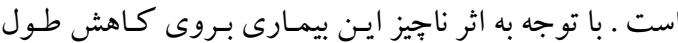
عمر بيماران، بِتانسيل ايجاد ناتوانى اين بيمارى براى سـالهاى

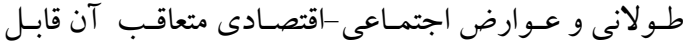
بحـث و توجـه اسـت.(1-(Y). از علائسم بــالينى آن ميتـوان اخستلال حسىى، حر كتى، مخجٍهـ اى ، اسـفنكترى، اخـتلال مسيرهاى حر كتى جشم، در گيرى اعصاب كرانيال(خصوصا

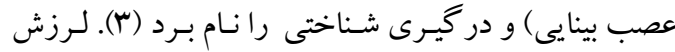

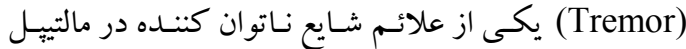
اسكلروزيس است كه ميتواند كيفيت زندگى را بايين آورده و فعاليتهاى روزانه فرد را محـدود كنــ. ترمـور يـك مشكل شايع در بيمارى ام اس است كه طى مطالعات انجام شده در

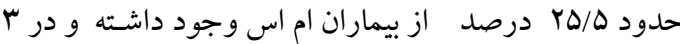
درصد آنها شـديد و بعضـا نـاتوان كنتـده بوده است (F-F).

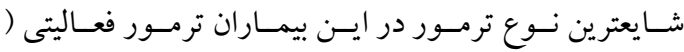
يوسجورال و اينتشن ) است و ترمور استراحت غير معمول مى باشد. ترمور مى تواند سر، گردن، طناب هاى صوتى، تنه و اندام ها را در گير كند كه البته بيشترين در گيرى در بازوهـا است. ترمور زبان، فكك و كام گزارش نشده اسـت. شـناخت ياتوفيزيولوزى دقيق ترمور در ام اس به علـت مـولتى فو كال بودن اين بيمارى دشوار است. در گيرى مخجِه، هسته هـاى تالاموسى و هسته هاى قاعـده اى از علل ذكر شــده هستـند (V)

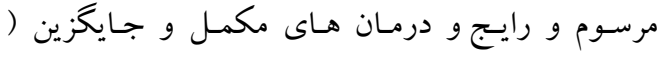
Complementary or Alternative Medicine داروهاى استفاده شده جهت درمان ترمور شامل: ايزونيازيد،

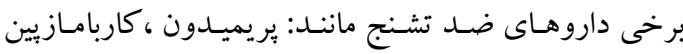

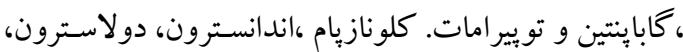


ضـــد اضــطراب، ضــد درد، ضـــد تشــنج، آرامبخشــى و نورويروتكتيو اسطوخودوس بوده است( اس-سM).

با توجه به اينكه طب سنتى داراى بشتوانه هاى تجربى فراوان از كشـورها، فرهنـگك و ادوار مختلـف اسـت، مسى توانـد در برخى حيطه ها در كنار طب مـدرن بـه درمـان علائسم صسعب العلاج مانند ترمور كمكك كند. به علاوه اين درمانها طبيعى هستند و ممكـن اسـت عـوارض جـانبى كمتـرى نسـبت بـه داروهاى صناعى داشته باشند. كه همين مسئله باعث بـذيرش بهتر دارو از طرف بيمار مى شود (MF). ذكر تئورى هـاى علـت ترمسور و توصسيه هـاى درمـانى در طب سنتى فارسى و كتابهاى داروشناسى دوران قرون وسطى از جمله كتاب قانون ابـن سـينا، منصسورى فى طـب رازى ، الاقراض الطب جرجانى نشان مى دهد كه با بررسى و مطالعه ى اين نسخ شايد بتوانيم به رويكردهاى جديدى در كنترل و درمان بيمارى ها و شرايط دشوار مثل ترمور دست بيدا كنيم

با توجه به اثبـات اثـرات مفيـد اسـطوخودوس بـر بسيارى از بيمـارى هـاى نورولوزيـكك در مطالعـات متعـدد نـوين و نيـز توجه به اين مسئله كه اين گياه حداقل از دوران قرون وسطى در درمان تشنج ، افسردگى ، ميگرن، اضطر اب ، درد، ترمور و نيسز جهـت آرام بخشى، توسط ابـن سيناو رازى توصسيه

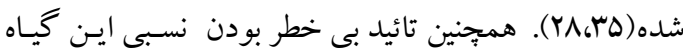

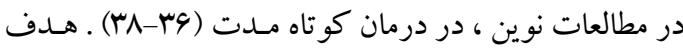
از انجام اين مطالعه تعيين تاثير گياه اسطوخودوس ايرانس بـر ترمور در بيماران مالتيبل اسكلروزيس است.

\section{مواد وروش ها}

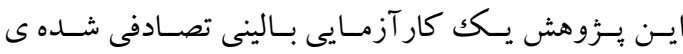
دوسـو كور بـود كـه در بـازه زمـانى ارديبهشـت وهما تـآذر

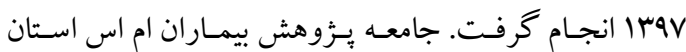
خوزسـتان كـه تحـت حمايست انجمـن ام اس اسـتان هسـتند بودومحيط انجام يـزوهش و آنـاليز داده هـا مركز تحقيقـات توانبخشى عضلانى - اسـكلتى واقع در دانشكده توانبخشى
يافتـه هــاى مطالعـات انجـام شــده در سـالهاى اخيـر بيـانكر اثربخشى برخى از تركيبات گياهى دربهبود بازسـازى ميلـين

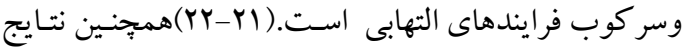

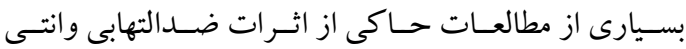

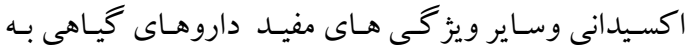
عنوان تر كيباتى طبيعى كبى خطر وقابل اطمينان بـراى درمـان بيمارى هاى سيستم عصـبى اسـت.(سY-YY) .نتـايج مطالعـات قبلى بيانكر ان است كه بيماران مبـتلا بـهـ ام اس بـراى درمـان و كنترل علايم بيمارى خود علاقه مند به استفاده از تر كيبـات

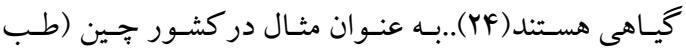
كياهى جينى)به طور گسترده ایى مورد استفاده بيماران ام اس لـ براى بهبود علايم بيمارى انهاسـت (YD). اثـرات مفيـد طـب كياهى جينى دربيمـارى ام اس از طريـق كـاهش شـدت ايـن

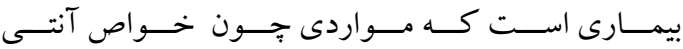

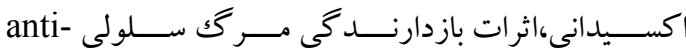
apoptotic ، اثرات ضدالتهابى وهدايت سلول هاى بنيادى

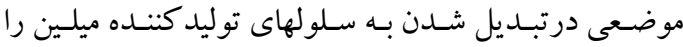
دربر ميكيرد(Y9). مديريت ترمور از جالشهاى جدى يزشكان است . درطب سـنتى بسـيارى از فرهنك هـاى ملـل جهـت درمان آن توصيه ها و درمانهايى ارائـه شـده اسـت. يكى از مهمترين منابع علوم يزشكى در قرون وسطى كتاب قانون ابن سينا بوده كه تا يايان قرن نوزدهم نيـز در بسـيارى از مـدارس يزشكى تدريس شده است. در كتاب قانون ابن سـينا لـرزش

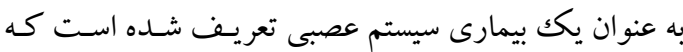
شامل همر اهى يـك سـرى حركـات غيـر ارادى بـا حركـات ارادى فـرد يـا ايجــاد ايـن حركـات در حالـت اسـتر احت

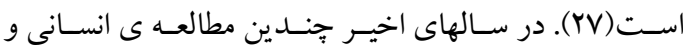

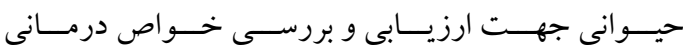
اسطوخودوس باروش هاى نوين علمى انجام شده است. اين

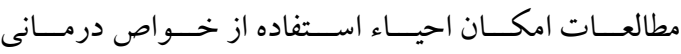

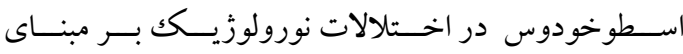
راقـوت مسى بخشــ (ري evidence-based medicine 9 Y). جندين مطالعه حيوانى انجـام شـده نشـان دهنـده ى اثر 
مثل آسم ، ديابت ،وجود سابقه حساسيت به اسطوخودوس و حمله ى بيمارى طى يكماه اخير بود.

نحوه تصادفى سازى افراد به گروه هاى مداخله و كنترل: بـراى Y^ بيمـار، تخصسيص تصـادفى براسـاس روش تشكيل بلوكى هاى جاى كشتى تصادفى أ تايى بـود. ب بيمـار ديخر هم بـه صسورت تصـادفى سـاده در هـر كـدام از خـروه هـاى مداخله و كنترل قرار كرفتند. نحوه كور سازى: افراد blind در ايسن مطالعـه شـامل مـوارد

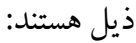
ا: يُزوهشخر كه با توجه به هـم شـكل بـودن داروى اصـلى و دارو نمـا اطلاعسى در مـورد اينكـه جـهـ بيمـارى كـداميكك را دريافت مى كند نداشت. r: افر اد مورد مطالعه نيز با توجه به توضيح ذكر شده فوق در مورد اينكه كداميك از گزينه هاى دارو /دارونما را دريافت مى كنند اطلاعى نداشتند. ب: كارشناس آناليز كننده ى داده هاى سيستم حر كت سنجى

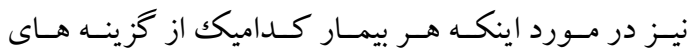
دارو /دارونما را دريافت مى كنند اطلاعى نداشت. ابزار جمع آورى اطلاعات شامل يرسشنامه ى بخشش ترمـور

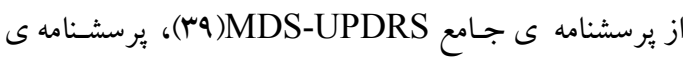
خـود ارزيـابى ،فـرم مخصـوص سـنجش EDSS، سيسـتم Motion Capture system با هفـت دوربسين مـادون قرمـز Qود. Qualisys ابتدا پس از تعيين وقت قبلى براى هر بيمار ، در بدو مراجعـه( زمـان صـفر ) از بيمـار شــرح حــال، معاينـه و تعيـين EDSS كارشناس مربوطه انجام شد. يس از ورود بيمـاران بـه محسيط

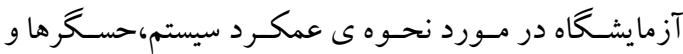

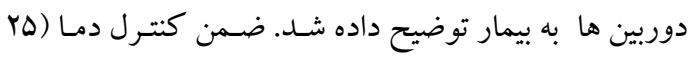
درجه)و سرو صداى محيط و نيز با يذيرايى شيرين از بيماران

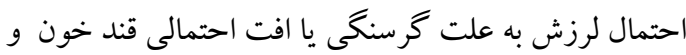
يا القا ترمور به دليل سر و صدا يا دماى نامناسـب محسيط، بـه حداقل رسيد. ساعت كار آزمايشگاه از ب عصر به بعد( زمـان

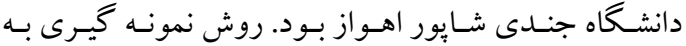
صورت نمونه گيرى در دسترس از ميان برونده هاى بيماران انجمن ام اس خوزستان بود. با توجه به عدم وجـود مطالعـات

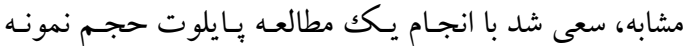
مورد نظر براى بررسى اثر بخشى مطالعـه تخمسين زده شـود و براى اين كار YF نفر انتخاب شدند كه طى مطالعه، جهار نفر از مطالعه خارج شدند.(دو نفر به علت عدم تمايل به ادامـهى همكارى ، يكك نفر به دليل حمله ى بيمارى در زمـان مطالعه و يكك نفر به علت عارضه ى احتمالى دارو بـه صسورت سـوء هاظمه ). براساس اثر بخش بودن نتيجه مطالعه در افر اد وارد

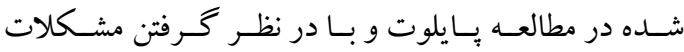
لجستيكى برنامه و كـاهش عـوارض احتمـالى مداخلـه مـورد نظر سعى شد تعداد نمونه ها انتخاب شـود طورى كـه تعـداد نمونه هاى مورد بررسى توانايى نشان دادن اثربخشى مداخله را داشته باشند و از طرف ديخـر هـم بـا توجـه اينكـه مطالعه مـذكور مداخلـه اى اسـت، تعـداد آزمـودنى هـاى بيشـتر در صورت هر گونهـ عـوارض احتمـالى ناخو اسـته و دراز مـدت ممكن است از نظر اخلاقى نقطه ضعفى بر بررسى اثر بخشى مداخله مذكور باشد. بر همين اساس حجم نمونه نهايى تعيين كرّديد. يعنى در نهايت تعداد ·ـ نفر از بيماران كه تمايـل بــه شر كت در مطالعه داشتند انتخاب شدند. معيارهاى ورود به مطالعه شامل داشتن بيمارى اثبات شـدهى ام اس با توجه به معاينات بالينى و سابقه بيمارى، داشتن امتياز EDSS

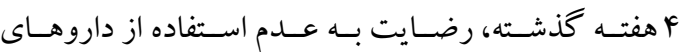
جايگزين از V روز قبل از شروع مداخله تا اتمام مداخله،عدم حضور در يكك مطالعه ديخر به صورت همزمان و سـن ها تـا •ه سال بود. معيارهاى خروج از مطالعه شامل سابقه مصرف الكل يا وابستخى بـه مواد،حـاملكَى يـا شـيردهى، اخـتلال در عملكرد كليوى و / يـا كبـدى،درمان بـا اسـتروئيدها در طـول يـكك مـاه قبـل از شـروع مطالعه،داشـن بيمـارى نرولوزيـك علاوه بر ام اس،بيمارى قلبى عروقى يـا بيمـارى هـاى ريـوى 
يا رسيدن به هدف نيز لحظه اى كه سرعت مذكور دوباره بـــ زير ه درصد مقدار بيشـينه اش بـر مسى گ حرد در نظر گرفتـه شـــ. بعــــ از تعيـين زمـان حركـت فاصـله ى حسـكر روى انخشت اشاره از خط فرضى واصل نقطه ى هدف و نقطه اى در فضا كه انگشت اشـاره يسس از كذشـت هل درصــ زمـان حركت در آن قرار دارد محاسبه شد. در نهايت ميانكين اين فاصله ى فضايى بين هم تا هو درصد زمان حر كت بـه عنـوان ميزان متوسط ترمور Intention محاسبه گرديد.

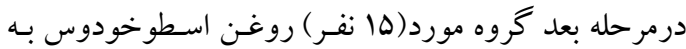

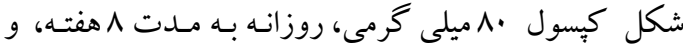
كروه كنترل (ها نفـر) كيسـول دارو نمـا روزانهه بـه مـدت هفته دريافت كردند. بيماران در هر دو مرحله ابتـدا در بايـان هفته ى اول مصـرف دارو / دارونمـا از نظـر شـرايط بـالينى و عـوارض احتمـالى بـه صـورت تلفنسى و بـه ترتيـب يسـ از كذشـت أو ^ هفتــه از شــروع مصـرف دارو بـه صـورت حضورى بيخيـرى و ارزيـابى شـدند. در يايـان هفتـه ى اول عوارض احتمالى دارو سوال شد. در پايان هفته ى fأو هفتـه

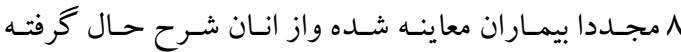
شدودرمورد عوارض احتمالى از بيمـار سـوال شـد. همجنـين EDSS محاسبه شــده و فـرم خـود ارزيـابى تكميـل شــــ بيماران با سيستم آناليز حر كت موردارزيابى قرار كرفتنـد. از خانمها در تمام مراحل ياد شده از وجود /عدم باردارى سوال شد. مرحله ى اصلى نيز دقيقا طبق نحوه ى مرحله ي بايلوت

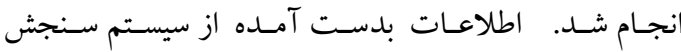
حركت بس از آناليز نهايى بـانـرم افزار MATLAB كـه دامنه ى ترمـور را بـا دقـت فراوان كمتـر از يـكك ميلـى متـر كزارش مسى داد يـس از تبـديل بـه سـانتى متـر بـا اسـتفاده از Tremor Research Group Scale

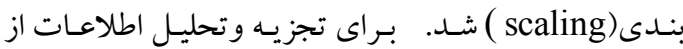
آزمونهاى من ويتنى يو و ويلككسون اسـتفاده گرديــ. ابتـدا نرمال بودن توزيع متغير ها با انجام تست k-S تست كرديــ. با توجه به نرمال نبودن توزيع هيج يكك از متغير ها داده ها در تمام مراحل از تسـت هـاى نايـارامترى اسـتفاده شــــ ابتـدا بـا
تعطيلى دانشكده) بود كه باعث شـد در حين كار سكوت مناسـبى برقـرار باشـــ. بـا بيمـار در مـورد داشـتن يـا نداشـتن اضطر اب احتمالى صحبت شد و يس از اطمينـان از آمـادگى بيمار و ير كردن بر سشنامه ى ( بخـش ترمـور از يرسشـنامه ى بيمار با قرار گرفتن در حالت نشسته بـروى MDS-UPRS صندلى راحت، حسكرهاى آزمون كه نشـانكرهاى بازتابنـده ى مادون قرمز هستند، توسط جسب دوطرفه ى ضد انعكاس روى دست و انگشتان جسبانده شد. به بيمار جهار وضسعيت متفاوت اندام هاى فوقانى جهت ثبـت ترمـور احتمـالى، داده شد. اين وضعيت ها شـامل اسـتراحت(REST ) ، حالـت نكَه داشتن وضعيت يكك (POSTURE1)، نحـه داشـتن وضسعيت دو (POSTURE2) و حركت (KINETIC) و د. هر وضعيت r

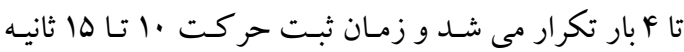
بود.جهت كمى كردن ميزان انواع ترمور بـه ثبـت حركـت و . لرزش هاى دست و انخشتان در حالتهاى مختلف آزمون نياز بود. بهترين و دقيـق تـرين روش ثبـت حركـات در حـوزهى كنترل حركت، استفاده از سيستم هاى ثبت حركت مبتنى بـر تصوير اسـت. در ايـن مطالعـه از يـك سيستم ثبـت حركت مادون قرمز هفت دوربينه سـاخت شـركت Qudisys سـوئد استفاده شد. سيستم ثبت حركت مختصـات سـه بعـدى ايـن نشانگر هدف و نشانكرهاى روى انگشتان را در فضا و حسين حركت بادقت كمتر از ا ميلى متر ثبت مى كرد. فركانس

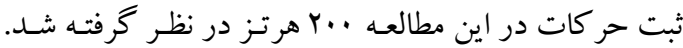
مختصات اين نشانكر ها براى آناليز بيشتر به نرم افزارى كه بـهـ همين منظور در محيط برنامسه ى نـرم افزارى MATLAB نوشته شده وارد شد. ابتدا مختصات حسكرها فيلتـر شـدند تـا اثر نويزهاى احتمالى از بين برود. سبس متغير كمى كنندهى ميزان هر كدام از انواع ترمور محاسبه شد. جهت محاسبه ى ترمـور intention يـا حركـت ابتـدا زمــان شـروع و ويايـان حر كت نقطه به نقطه ى انكگت اشاره به سمت هـدف تعيـين شـد. زمـان شـروع ترمـور لحظه اى در نظـر كرفتـه شـد كـه سـرعت حركـت نشـانكر روى انخشـت اشـاره از ه درصــ سرعت آن بيشتر مى شود. در جِنين لحظه اى پايـان حركت 


\section{يافته ها}

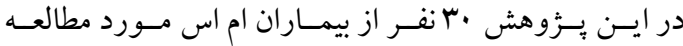

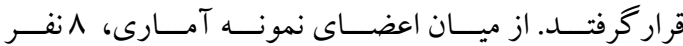

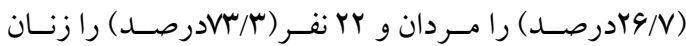
تشكيل مى دهند كه به صورت تصادفى بـه دو گرووه تقسيم

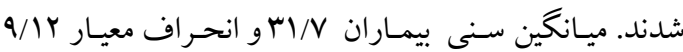

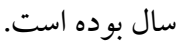

اسـتفاده از آزمـون نايــارامترى ويلكاكســـن ميـزان شـــت ترومور در هفته هشتم با شدت ترمهور قبـل از شـروع درمكان به تفكيك براى هر گروه محاسبه شد.

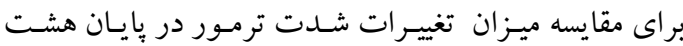
هفته درمان و قبل از شروع درمان، بين دو گحروه بيماران ام اس دريافت كننده گياه اسطوخودوس و دريافت كنــده دارو نما از آزمون من-ويتنى استفاده شده است.

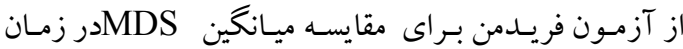
هاى مختلف (قبل از شروع درمان، هفته F ، هفتهـ) استفاده

جدول ا. ويزگى هاى بيماران حاضر در دو كروه دارو و دارو نما

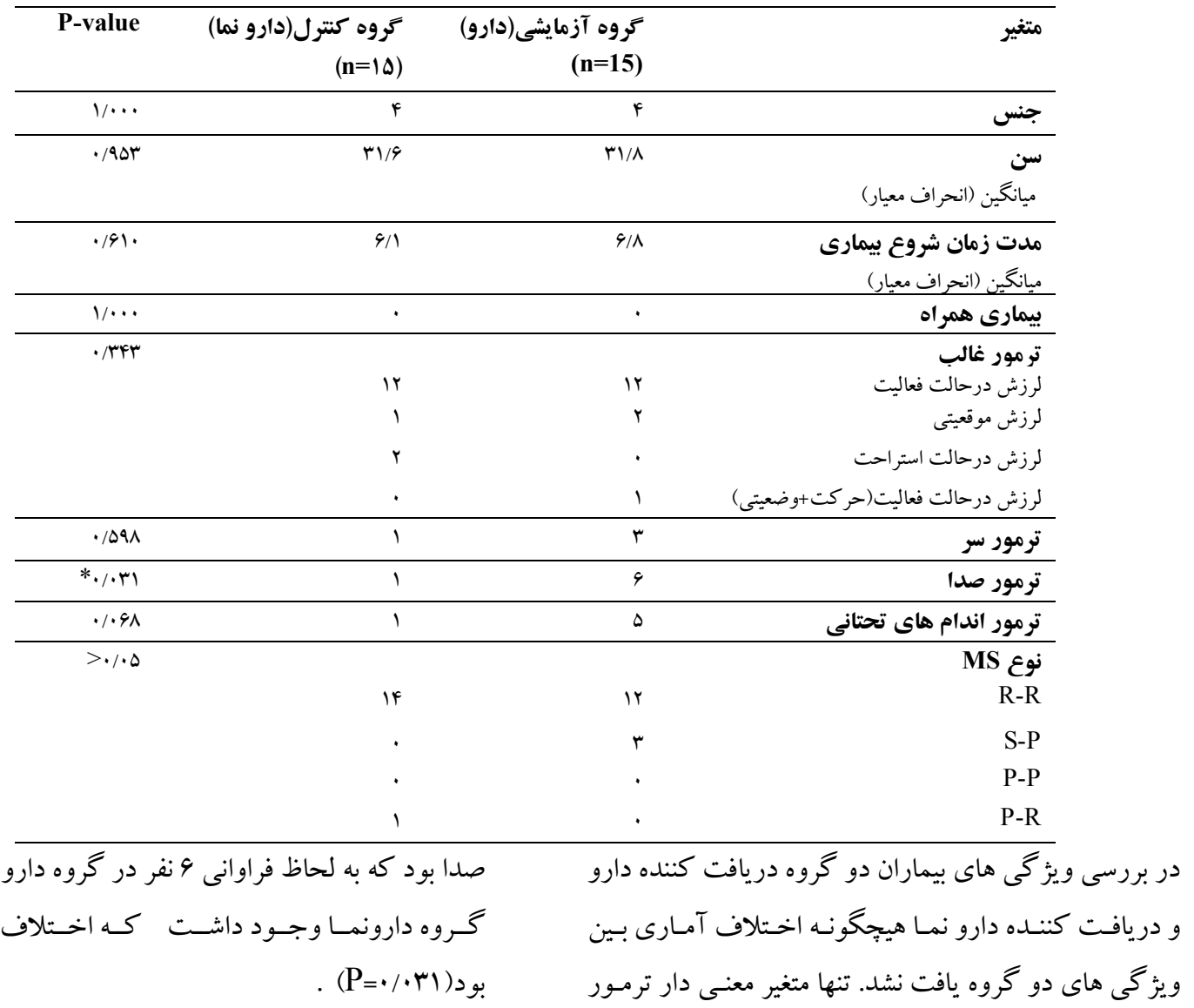




\begin{tabular}{|c|c|c|c|c|c|c|}
\hline P-value & Tاره Z & انحر اف & ميانكين & تعداد & متغير & كروه \\
\hline .1 .94 & $-1 / \wedge \Delta V$ & $\begin{array}{l}\cdot / \mathrm{VH} \\
\cdot / 94\end{array}$ & $\begin{array}{l}1 / \Delta V \\
1 / Y V\end{array}$ & 10 & ترمور درحالت استراحت(قبل از درمان) & دارو \\
\hline$\cdot / 09$ & $-1 / \wedge 9$ & $\begin{array}{l}\cdot / 09 \\
\cdot / 09\end{array}$ & $\begin{array}{l}\text { l/Ar } \\
\text { I/9V }\end{array}$ & $\begin{array}{l}10 \\
10\end{array}$ & ترمور درحالت استراحت(قبل از درمان) & دارونما \\
\hline$\cdot / \cdot r^{* *}$ & $-r / \cdots$ & $\begin{array}{l}\cdot / \Delta \Lambda \\
\cdot / \Delta 4\end{array}$ & r/9r & 10 & ترمور وضعيتى ((قبل از درمان) & دارو \\
\hline . & -I/VRr & $\begin{array}{l}\cdot / \mu V \\
\cdot / 4\end{array}$ & 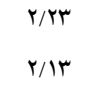 & $\begin{array}{l}10 \\
10\end{array}$ & ترمور وضعيتى ((قبل از درمان) & دارونما \\
\hline.$/ \cdot 1 f^{*}$ & $-r / 499$ & $\begin{array}{l}\cdot / \Delta r \\
\cdot / \Delta \Delta\end{array}$ & $\begin{array}{l}/ \Delta V \\
r / T V\end{array}$ & 10 & ترمور وضعيتى r(قبل از درمان) & دارو \\
\hline.$/ 0 \wedge 9$ & $-\cdot / \Delta F \mid$ & $\begin{array}{l}\cdot / \Delta r \\
\cdot / F r\end{array}$ & $\begin{array}{l}r / l V \\
r / l .\end{array}$ & $\begin{array}{l}10 \\
10\end{array}$ & ترمور وضعيتى r(قبل از درمان) & إدارونما \\
\hline$\cdot / \cdot r^{* *}$ & $-r / \ldots$ & $\begin{array}{l}/ Y F \\
\cdot / \mu\end{array}$ & $\begin{array}{l}r / 9 V \\
r / r V\end{array}$ & 10 & ترمور درحالت حركت(قبل از درمان) & دارو \\
\hline$\cdot / \cdot 1$ & -r/949 & $\begin{array}{l}\cdot / \text { M } \\
\cdot / 4 V\end{array}$ & $\begin{array}{l}r / 9 V \\
r / F r\end{array}$ & $\begin{array}{l}10 \\
10\end{array}$ & ترمور درحالت حركت(قبل از درمان) & دارونما \\
\hline
\end{tabular}

جدول "ا. ميزان تغييرات شدت ترمور در يايان هشت هفته درمان و قبل از شروع درمان در دو كروه دريافت كننده دارو و دارو نما.

\begin{tabular}{|c|c|c|c|c|c|c|}
\hline P-value & Tارo & Man-WhitneyU & انحراف استاندار & ميانكين & كروه & متغير \\
\hline \multirow[t]{3}{*}{.$/ 910$} & $-\cdot / 1 \cdot V$ & $11 \cdot / 0$ & $\cdot / \Delta V$ & $-\cdot / r$. & دارو & ترمــور درحالــت \\
\hline & & & & & & استراحت \\
\hline & & & $\cdot / \Delta F$ & $-\cdot / \cdot r r$ & كنترل & \\
\hline \multirow[t]{2}{*}{.$/ \cdot F 1^{*}$} & $-r / 191$ & $9 V / 0$ & $1 / 9$. & א & دارو & ترمور وضعيتى 1 \\
\hline & & & $\cdot 109$ & $-\cdot / 4 q$ & كنترل & \\
\hline \multirow[t]{2}{*}{ •/4^9 } & $-1 / \cdots 1$ & $91 / 0$. & I/VD & $-1 / T r$ & دارو & ترمور وضعيتى r \\
\hline & & & $\cdot / \mathrm{NI}$ & $-\cdot / \Delta r$ & كنترل & \\
\hline \multirow[t]{2}{*}{. $/ \Delta r_{q}$} & $-\bullet / V Y$ & $9 V / 0$. & $\cdot / 9$ & $-\cdot / 91$ & دارو & ترمسـور درحالـت \\
\hline & & & $1 / \cdot r$ & -.199 & كنترل & حركت \\
\hline
\end{tabular}

.

براى هر سه متغير ديكر ميانكين در يايان هفته هشتم به طـور. معنى دارى كاهش يافته است. ( ه •/

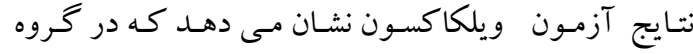
دريافت كننده دارو بين ميانگين Rest در هفته هشتم و قبـل

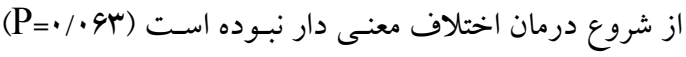




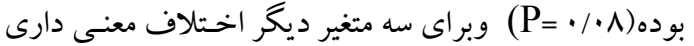
بين ميانگين هفته هشتم و قبل از شروع درمان وجـود نداشـته

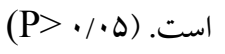

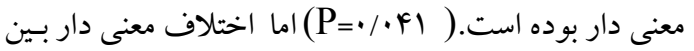
ميزان تغييرات متغيرهاى ترمسور درحالت استراحت، ترمسور درحالت وضـعيتى ب و ترمـور درحالت حركت دو گركروه

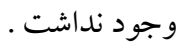

در گـروه دريافـت كنـــده دارونمـا تنهـا بـراى متغيــر ترمـور درحالت حر كت ميزان اختلاف بين هفته هشتم (M=r/9V)

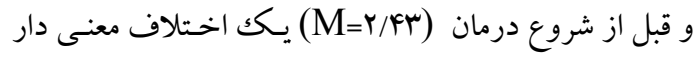
نتايج آزمون نشان مى دهد كه بعد از كذشت م هنته از آ آغاز درمان متوسط ميزان كاهش متغير ترمور وضعيتى ادر گروه

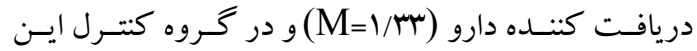
كاهش ( (ب//•) بوده كـه ايـن اختلاف از نظر آمـارى

جدول F. مقايسه خودارزيابى هفته جهارم و هفته هشتم بين دو كروه

\begin{tabular}{|c|c|c|c|c|c|c|}
\hline P-value & 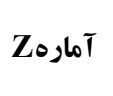 & Man-WhitneyU & استاندارد اف اف & ميانغين & كروه & متغير \\
\hline \multirow[t]{2}{*}{$\cdot / 09 V$} & \multirow[t]{2}{*}{$-\cdot / 9 R T$} & \multirow[t]{2}{*}{$9 \wedge / \cdot}$. & $\cdot / \wedge 9$ & $r / \Lambda$. & 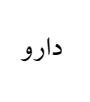 & \multirow[t]{2}{*}{ خود ارزيابى } \\
\hline & & & $1 / Y F$ & $r / \Delta r$ & كنترل & \\
\hline \multirow[t]{2}{*}{$.19 \lambda \mu$} & \multirow[t]{2}{*}{$-\cdot / 4 \cdot 1$} & \multirow[t]{2}{*}{$1 . r /}$. & $1 / 1$. & $r / N r$ & دارو & \multirow{2}{*}{ خود ارزيابى 1 هفته } \\
\hline & & & $1 / \Delta F$ & $r / 9 V$ & كنترل & \\
\hline . /944 & $-\cdot / \cdot \wedge$ & $91 / 0$. & $\begin{array}{l}.11 . \\
1 / .9\end{array}$ & $\begin{array}{l}-.1 .94 \\
. / 1 \mu r\end{array}$ & كنت ل دارو & ميزان تغيير \\
\hline
\end{tabular}

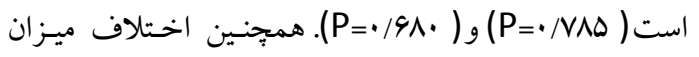
خودارزيابى بيمـار در هفتـه جهارم و هفتـه م بـين دو گحروه

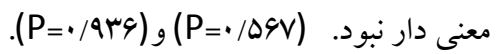

نتايج آزمون ويلكاكسون نشـان داد كـه در گـروه دريافت كننده دارو و گرووه دريافت كننده دارونما اختلاف بين خـود ارزيابى هفته هشتم و قبل از شـروع درمـان معنى دار نبـوده

جدوله. مقايسات زوجى براى بررسى اختلاف معنى دار بين ميانكين MDS در كروه دارو

\begin{tabular}{|c|c|c|}
\hline & $\mathrm{P}$-value & (J) \\
\hline \multirow[t]{3}{*}{$\overline{<\cdot / . .1^{* *}}$} & هفته & قبل از آزمون \\
\hline & هفته |م|// > > > & قبل از آزمون \\
\hline & هفته / |./•> & | هفته ب \\
\hline
\end{tabular}

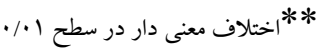

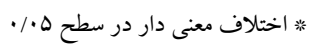

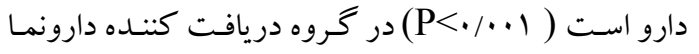
نتايج آزمون فريدمن نشان دهنده وجود اخـتلاف معنى دار اين اختلاف معنى دار نبود (P= (PV) بين ميانگين MDS در سه زمان در گروه دريافت كننـه 
جدول 9. ميزان تغييرات MDS

\begin{tabular}{|c|c|c|c|c|c|c|}
\hline p-value & Zارمار & Man-WhitneyU & استاندارد انحر & ميانكين & كروه & متغير \\
\hline \multirow{3}{*}{$.1 .4 q^{*}$} & & & & & & تغيير ات هفته f نسبت \\
\hline & $-1 / 909$ & $V \Delta / \cdot \cdot$ & $\cdot / \Delta r$ & $-\cdot / \& V$ & دارو & به قبل از شروع \\
\hline & & & . & $-\cdot / \mu$ & كنترل & \\
\hline \multirow[t]{2}{*}{$\cdot / \cdot v r^{*}$} & $-1 / V 90$ & $\Delta r / \Delta$. &.$/ 49$ & - & دارو & تغييرات هفته ^ نسبت \\
\hline & & & $\cdot / 149$ & $-\cdot / \cdot V$ & كنترل & به هفته F \\
\hline \multirow[t]{3}{*}{$\cdot / \cdot 1^{* *}$} & ו ו ו & $F \Delta / .$. & $\cdot / 41$ & $-\cdot / A$ & دارو & تغيير ات هفته ^ نسبت \\
\hline & & & & & & به قبل از \\
\hline & & &.$/ 41$ & $-\cdot / r$ & كنترل & شروع درمان \\
\hline
\end{tabular}

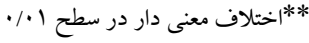

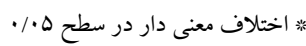

معنادارى در كاهش شدت ترمور مشـاهده نشـــبـا توجـه بــ نتايج آناليز داده هاى اين مطالعه روغن كيـاه اسطوخودوس اير انى با حداقل دوز •ميلى گرم در كاهش ترمسور بيمـاران

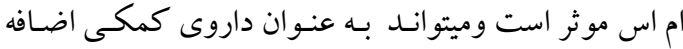
شونده يا به تنهايى مورد استفاده قرار گيرد. در سالهاى اخير جنــين مطالعه ى انسـانى و حيـوانى جهـت ارزيابى و بررسى خواص درمانى اسطوخودوس كه در طب سنتى استفاده مى شده - با روش هاى نوين علمى انجام شـده است. اين مطالعات امكان احياء اسـتفاده از خـواص درمـانى

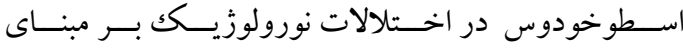

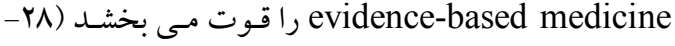
99). تاثير گياه اسطوخودوس بر ترمور تاكنون مورد بررسى قرار نكخرفته اسـت امـا بررسى نتـايج مطالعـات انجـام شـده برروى انسان وحيوان حاكى از اثربخشى اين گياه در درمـان. بيمارى هاى مختلف بوده است. جندين مطالعه حيو انى انجام شده نشان دهنده ى اثر ضد اضطراب، ضد درد، ضـد تشـنج،
نتايج آزمون نشان مى دهد كه بعد از كذشت ^ هفته از آغـاز درمـان متوسـط ميـزان كـاهش MDS در گـروه دريافـت

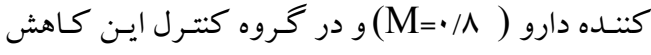
بوده كـه اختلاف بـين دو گـروه معنى دار بـوده $(\mathrm{M}=\bullet / Y)$ است . ( نتايج اين مطالعه بيانكر اختلاف معنى دار در گروه دريافت كننده دارو براى سه متغير ترمور وضعيتى ا, ترمور وضسيتى rو ترمور درحالت حركـت بـود.بسين ميـانگين اسـتراحت در هفته هشتم و قبل از شـروع درمـان اختلاف معنسى دار نبـوده است .براى گـروه دارونمـا، ايسن اخـتلاف معنى دار تنها در متغير ترمور درحالـت حركت مشـاهده شـده اسـت .صـرفا براى متغير ترمور وضعيتى اميزان كاهش شدت ترمـور بعـد از ^هفته بـراى گـروه دريافت كنتـده دارو بيشـتر از گحروه دارونما بوده است و براى متغير هاى ديخًر اختـلاف آمـارى 
بيماران بخش مر اقبتهاى ويزّه ، همودياليز و در زنان بر خطر

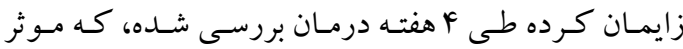
كز ارش شده است(

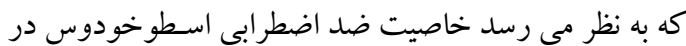
افراد با شدت اضطراب كم موثر بوده و اين اثر بخشى شـايد قابل تعميم به انواع شديد اضطراب نباشد (ه).

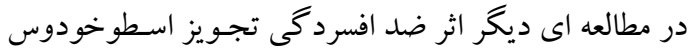

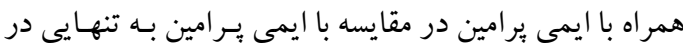

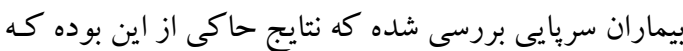
همر اهى Y دارو موجب اثر بيشتر و سريعتر در درمـان علائم افسردىى شده است. به نظر مس رسـد برخى بيمـارى هـاى إى

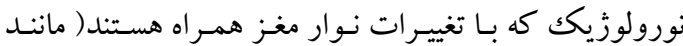

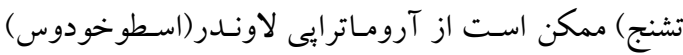

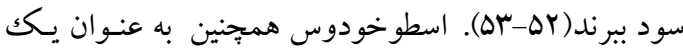
درمان طبيعى عالى جهت بهبود كيفيـت خـواب و در درمان بى خوابى نامبرده شده است.در مطالعات متعـدد انجـام شـده

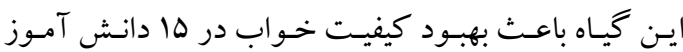

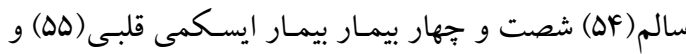

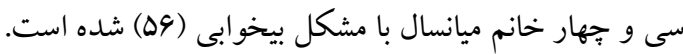

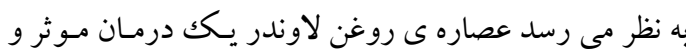

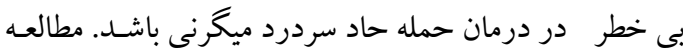
اى در همـين زمينه بـروى FV بيمـارى كـه حمـلات سـردرد ميكرنى داشتند، كاهش قابل توجه شدت درد و علائم همراه

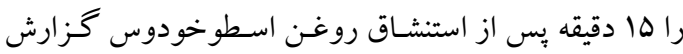

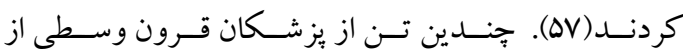

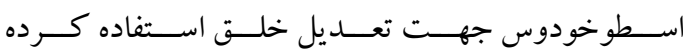
اند) ( اند (

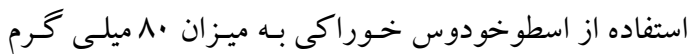
يكبار در روز به مدت 9 هفته در بيماران نوراستنى يا اختلال

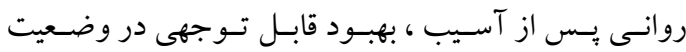

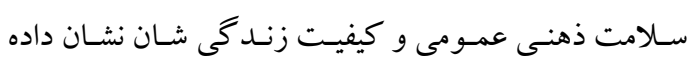

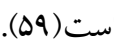

آرامبخشى و نورويروتكتيو اسطوخودوس بوده اسـت. اثر اسـطوخودوس بــه عنـوان ضــــ اضـطر اب در مقايسـهـ بــا

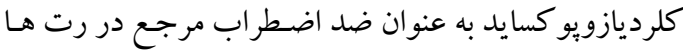

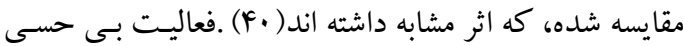
موضعى اسطوخودوس و مشتقات آن به صورت INVIVO

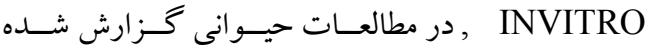
است(أ). تجويز خـوراكى يـا استنشاقى اسطوخودوس بـه صـورت قابـل تـوجهى درد حرارتسى و شـيميايى را بــدون شـواهلى از عـوارض جـانبى سيستم اعصـاب مركـزى در

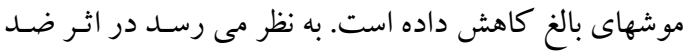

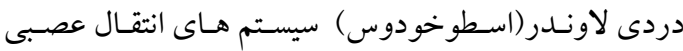
اوييوئيدرزيك و كولينرزيك موثر باشند. تجويز نالو كسان و

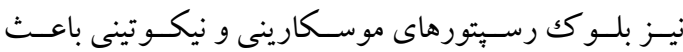
جلو گيرى از اثر ضـد دردى اسطوخودوس مسى شـود(FY) عصـارهى هيـدروالكليكك اسطوخودوس در تشـنج باعـث

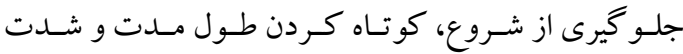
حملات تشنجى القا شده توسط مواد شيميايى در مـدل هـاى لون

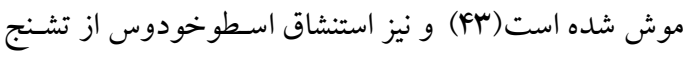

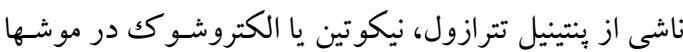

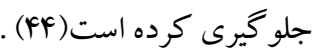
اين گياه اثر محافظتى از سيستم عصبى در شـرايط ايسكمى

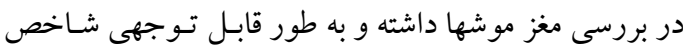
نقص عصبى، اندازه انفاركت و آسيب سـلو لهاى عصبيى را كاهش داده كه احتمالا مرتبط با اثر ضد اكسيدانى آن اسـت

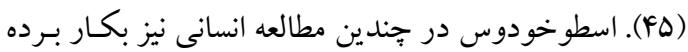

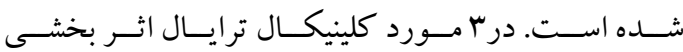

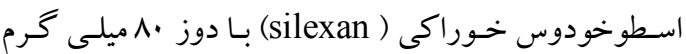

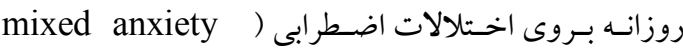
disorder, Generalized anxiety disorder آزيتاسون و بيقرارى ) در مقايسه با بِلاسبو بيشتر بوده است و

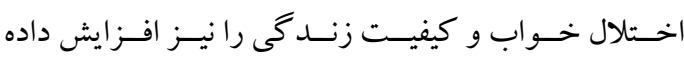

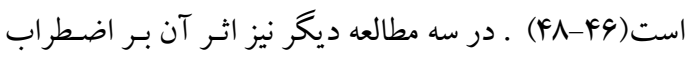




$$
\begin{aligned}
& \text { نتايج بزوهش حاضر بيانكر ان است كه درمان كوتاه مدت با ماليدنى و آروماترايى) در حقيقت از نظر اثر بخش بـودن بـا } \\
& \text { اسطوخودوس نسبتا بى خطر است. بهر حسال گزارشاتى از } \\
& \text { عوارض جانبى آن وجود دارد. زنيكوماستى كه بس از قطع }
\end{aligned}
$$

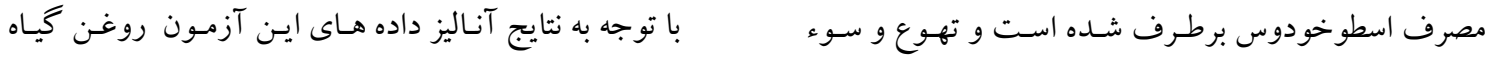

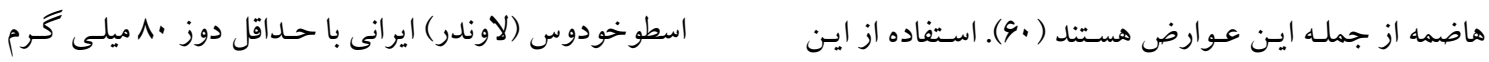

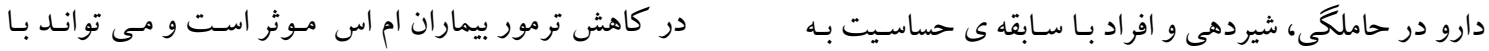

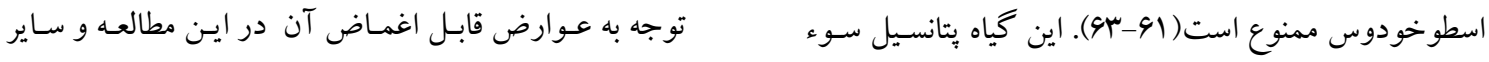

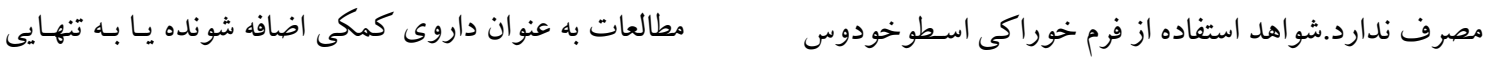

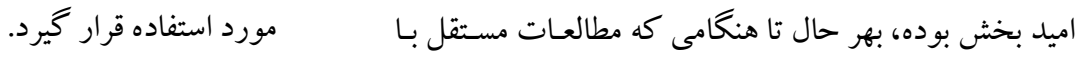

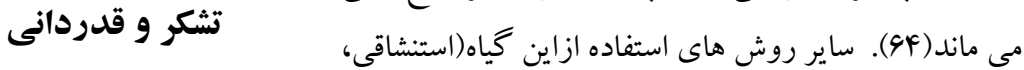

منابع

1.Daroff RB, Fenichel GM, Jankovic J, Mazziotta JC, eds. Bradley's Neurology in Clinical Practice. 6thEdition, Vol. I: Principles of Diagnosis and Management, Vol. II: Neurological Disorders. Elsevier Saunders. 2012:2544.

2.Solaro C, Ponzio M, Moran E, et al. The changing face of multiple sclerosis: Prevalence and incidence in an aging population. Mult Scler 2015; 21:1244-50.

3.Marrie RA. Comorbidity in multiple sclerosis: implications for patient care. Nat Rev Neurol 2017; 13:375-82.

4. Mostert J, Heersema D, De Keyser J.Tremor in multiple sclerosis. J Neurol (2007) 254:133-145.

5.Koch M, Mostert J, Heersema D, De Keyser J. Tremor in multiple sclerosis. J Neurol. 2007;254(2):133-145.

6.Alusi SH, Glickman S, azizi TZ, et al. Tremor in multiple sclerosis, Journal of Neurology, Neurosurgery \& Psychiatry 1999;66:131-134.

7.Rinker JR, Salter AR, Walker H, Amara A, Meador W, Cutter GR. Prevalence and characteristics of tremor in the NARCOMS multiple sclerosis registry: a cross-sectional survey. BMJ Open. 2015;5(1): e006714. Published 2015 Jan 8. doi:10.1136/bmjopen-2014-006714.

8.Yadav V, Bever C Jr, Bowen J, Bowling A, Weinstock-Guttman B, Cameron M, et al. Summary of evidence-based guideline: Complementary and alternative medicine in multiple sclerosis: report of the guideline development subcommittee of the American Academy of Neurology. Neurology 2014;82(12):1083-92.

9.Esmonde L, Long AF. Complementary therapy uses by persons with multiple sclerosis: benefits and research priorities. Complement Ther Clin Pract. 2008 Aug;14(3):176-84.

10.Mirzai V, Saiadi A, Heydarinasab M. [Knowledge and attitude of Rafsanjan physicians about complementary and alternative medicine]. Tabebe shargh. 2011; 13(6):20-24. Persian

11.Apel-Neu A, Zettl UK. Complementary and alternative medicine in multiple sclerosis. J Neurol. 2008;255: 6:82-6.

12.Agyare C, Spiegler V, Asase A, Scholz M, Hempel G, Hensel A. An ethnopharmacological survey of medicinal plants traditionally used for cancer treatment in the Ashanti region, ghana. J Ethnopharmacol 2018; 212:137-52. doi: 10.1016/j.jep.2017.10.019

13.Dehghan-Shahreza F, Beladi-Mousavi SS, Rafieian-Kopaei M. Medicinal plants and diabetic kidney disease; an updated review on the recent findings. Immunopathol Persa 2016;2(1): 40.

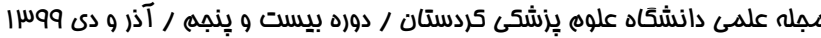


14.Goodin DS, Frohman EM, Garmany GP, Jr., Halper J, Likosky WH, Lublin FD, et al. Disease modifying therapies in multiple sclerosis: report of the Therapeutics and Technology Assessment Subcommittee of the American Academy of Neurology and the MS Council for Clinical Practice Guidelines. Neurology. 2002 Jan 22;58(2):169-78.

15.Freeman JA, Thompson AJ, Fitzpatrick R, Hutchinson M, Miltenburger C, Beckmann K, et al. Interferon-betalb in the treatment of secondary progressive MS: impact on quality of life. Neurology.2001; 57(10):1870-5.

16.Apel-Neu A, Zettl UK. Complementary and alternative medicine in multiple sclerosis. J Neurol.2008;255 (6):82-6.

17.Nayak S, Matheis RJ, Schoenberger NE, Shiflett SC. Use of unconventional therapies by individuals with multiple sclerosis. Clin Rehabil. 2003;17(2):181-91.

18.Kim S, Chang L, Weinstock-Guttman B, Gandhi S, Jakimovski D, Carl E, et al. Complementary and alternative medicine usage by multiple sclerosis patients: Results from a prospective clinical study. J Altern Complement Med 2018;24(6):596-602. doi: 10.1089/acm.2017: 20;68.

19.Dayapoglu N, Tan M. Use of complementary and alternative medicine among people with multiple sclerosis in eastern turkey. Neurology Asia 2016;21(1):63-71.

20.Seddighi Zh, Mafton F, Moshrafi M. [Knowledge and insight to complementary medicine and the rate of the service population of Tehran, monitoring]. Payesh. 2005. 3(4): 279-89.

21.Mohajeri M, Sadeghizadeh M, Najafi F, Javan M. Polymerized nano-curcumin attenuates neurological symptoms in eae model of multiple sclerosis through down regulation of inflammatory and oxidative processes and enhancing neuroprotection and myelin repair. Neuropharmacology 2015; 99:156-67. doi: 10.1016/j.neuropharm.2015.07.013

22. Piao Y, Liang X. Chinese medicine in diabetic peripheral neuropathy: Experimental research on nerve repair and regeneration. Evid Based Complement Alternat Med 2012; 2012:191632. doi: $10.1155 / 2012 / 191632$.

23.Kaplan M, Mutlu EA, Benson M, Fields JZ, Banan A, Keshavarzian A. Use of herbal preparations in the treatment of oxidant-mediated inflammatory disorders. Complement Ther Med 2007;15(3):20716. doi: $10.1016 /$ j.ctim.2006.06.005

24.Olsen SA. A review of complementary and alternative medicine (CAM) by people with multiple sclerosis. Occup Ther Int 2009;16(1):57-70. doi: 10.1002/oti.266

25.Miller RE. An investigation into the management of the spasticity experienced by some patients with multiple sclerosis using acupuncture based on traditional chinese medicine. Complement Ther Med 1996;4(1):58-62. doi: 10.1016/S0965-2299(96)80058-6

26.Song L, Zhou QH, Wang HL, Liao FJ, Hua L, Zhang HF, et al. Chinese herbal medicine adjunct therapy in patients with acute relapse of multiple sclerosis: A systematic review and meta-analysis. Complement Ther Med 2017; 31:71-81.

27.Avicenna (1999). The Canon of Medicine (al-Qānūn fíl-tịbb), vol. 1. Laleh Bakhtiar (ed.), Oskar Cameron Gruner (trans.), Mazhar H. Shah (trans.). Great Books of the Islamic World. ISBN 978-1871031-67-6.

28.Vakili N. Gorji A. Psychiatry and psychology in medieval Persia," Journal of Clinical Psychiatry. 2006;67(12): 1862-1869.

29.Gorji A, Khaleghi Ghadiri M. History of epilepsy in Medieval Iranian medicine," Neuroscience and Biobehavioral Reviews. 2001;25(5): 455-461.

30.Gorji A, Ghadiri, M. History of headache in medieval Persian medicine," Lancet Neurology. r..r; $; 1(8): 510-515$.

31.Buchbauer G, Jirovetz L, Jagger W, H. Dietrich, and C. Plank, "Aromatherapy: evidence for sedative effects of the essential oil of lavender after inhalation," Zeitschrift fur Naturforschung. 1991;46(11-12): 1067-1072.

32Kashani M. STavirani, M. R, Talaei S, Salami M. Aqueous extract of lavender (Lavandula angustifolia) improves the spatial performance of a rat model of Alzheimer's disease,"Neuroscience Bulletin. 2011;27(2): 99-106.

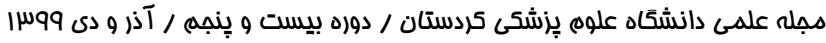


33.Lis-Balchin M, Hart S.Studies on the mode of action of the essential oil of lavender (Lavandula angustifolia P. Miller). Phytotherapy Research.1999: 13; 540-542.

34.Zargaran A, Zarshenas M, Mehdizadeh A, Mehdizadeh A.Management of Tremor in Medieval persia Journal of the History of the Neurosciences.2013; 22:53-61.

35.Xu F, Uebaba K, Ogawa H et al. Pharmaco-physiopsychologic effect of ayurvedic oil-dripping treatment using an essential oil fromLavendula angustifolia, Journal of Alternative and Complementary Medicine. 2008;14(8): 947-956.

36.Henley D. V, Lipson N, Korach, KS, Bloch CA. Prepubertal gynecomastia linked to lavender and tea tree oils," New England Journal of Medicine. ${ }^{\text {. . } \vee ~}$;356(5): 479-485.

37.Brand ao F. M. Occupational allergy to lavender oil," Contact Dermatitis. 1986;15(4): 249-250.

38.Sugiura M, Hayakawa R, Kato Y, Sugiura K, Hashimoto R. Results of patch testing with lavender oil in Japan," Contact Dermatitis. 2000;43(3): 157-160.

39.Martinez-Martin P, Rodriguez-Blazquez C, Alvarez-Sanchez M, Arakaki T, Bergareche-Yarza A, Chade A, Garretto N, Gershanik O, Kurtis MM, Martinez-Castrillo JC, Mendoza-Rodriguez A, Moore HP, Rodriguez-Violante M, Singer C, Tilley BC, Huang J, Stebbins GT, Goetz CG. Expanded and independent validation of the Movement Disorder Society-Unified Parkinson's Disease Rating Scale (MDS-UPDRS). J Neurol. 2013;260(1):228-36.

40.Umezu T. Behavioral effects of plant-derived essential oils in the Geller type conflict test in mice," Japanese Journal of Pharmacology. 2000;83(2): 150-153.

41.Lim W. C, Seo J. M, Lee C. I, Pyo H. B, Lee, B. C. Stimulative and sedative effects of essential oils upon inhalation in mice," Archives of Pharmacal Research. 2005;28(7): 770-774.

42.Buchbauer G, Jirovetz L, J"ager W, Dietrich H, Plank C. Aromatherapy: evidence for sedative effects of the essential oil of lavender after inhalation. Zeitschrift fur Naturforschung. 1991;46(11): 1067-1072.

43.Kashani M. S, Tavirani M. R, Talaei S. A, Salami M. Aqueous extract of lavender (Lavandula angustifolia) improves the spatial performance of a rat model of Alzheimer's disease,"Neuroscience Bulletin. 2011;27(2): 99-106.

44.Lis-Balchin M., Hart S. Studies on the mode of action of the essential oil of lavender (Lavandula angustifolia P. Miller)," Phytotherapy Research. 1999;13: 540-542.

45. Silva Brum L. F, Elisabetsky E, Souza D. Effects of linalool on [3H] MK801 and [3H] muscimol binding in mouse cortical membranes," Phytotherapy Research. 2001;15(5):422-425.

46.Kasper S, Gastpar M, M"uller W. E. et al. Efficacy and safety of silexan, a new, orally administered lavender oil preparation, in subthreshold anxiety disorder-evidence fromclinical trials,'WienerMedizinischeWochenschrift. 2010;160(21): 547-556.

47.Woelk H, Schl"afke S. A multi-center, double-blind, randomised study of the Lavender oil preparation Silexan in comparison to Lorazepam for generalized anxiety disorder," Phytomedicine.2010;17(2): 94-99.

48.Dunn C, Sleep J, Collett D.Sensing an improvement:an experimental study to evaluate the use of aromatherapy,massage and periods of rest in an intensive care unit," Journal of advanced nursing. 1995;21(1): 34-40.

49.Walsh E, Wilson C. Complementary therapies in long-stay neurology in-patient settings," Nursing Standard. 1999;13(32):32-35.

50.Conrad P, Adams C. The effects of clinical aromatherapy for anxiety and depression in the high risk postpartum woman - a pilot study," Complementary Therapies in Clinical Practice. 2012;18(3): 164-168.

51.Braden R, Reichow S, Ahalm A. Theuse of the essential oil Lavandin to reduce preoperative anxiety in surgical patients," Journal of Perianesthesia Nursing.2009;24(6):348-355.

52.Morris N. The effects of lavender (Lavendula angustifolium) baths on psychological well-being: two exploratory randomized controls trials," Complementary Therapies in Medicine.2002;10(4): 223228. 
53.Sanders C, Diego M, Fernandez M, Field T, Hernandez- Reif, M Roca M. EEG asymmetry responses to lavender and rosemary aromas in adults and infants," International Journal ofNeuroscience. 2002;112(11): 1305-1320.

54.Hirokawa K, Nishimoto T, Taniguchi T.Effects of lavender aroma on sleep quality in healthy Japanese students,"Perceptual \& Motor Skills. 2012;114(1): 111-122.

55.Hirokawa K, Nishimoto T, Taniguchi T.Effects of lavender aroma on the quality of sleep in ischemic heart diseaselavender aroma on sleep quality in healthy Japanese students,"Perceptual \& Motor Skills. 2012;114(1): 111-122.

56. Chien L. W, Cheng S. L, Liu C. F. The effect of lavender aromatherapy on autonomic nervous system in midlife women with insomnia," Evidence-Based Complementary and AlternativeMedicine. 2012; 11:8.

57.Woronuk G, Demissie Z, Rheault M, Mahmoud S. Biosynthesis and therapeutic properties of lavandula essential oil constituents," Planta Medica. 2011;77(1): 7-15.

58.Jager W, Buchbauer G, Jirovetz L, Fritzer M. Percutaneous absorption of lavender oil from a massage oil," Journal of the Society of Cosmetic Chemists. 1992;43:49-54.

59.Uehleke B, Schaper S, Dienel A, Schlaefke S, Stange R. Phase II trial on the effects of Silexan in patients with neurasthenia, post-traumatic stress disorder or somatization disorder," Phytomedicine. 2012;19(8-9): 665-671.

60.Sugiura M, Hayakawa R, Kato Y, Sugiura K,.Hashimoto R.Results of patch testing with lavender oil in Japan,"Contact Dermatitis. 2000;43(3):157-160.

61.Henley D. V, Lipson N, Korach K. S, Bloch C.A. Prepubertal gynecomastia linked to lavender and tea tree oils,"New England Journal of Medicine.2007:356(5): 479-485.

62.Sugiura M, Hayakawa R, Kato Y, Sugiura, K,.Hashimoto R. Results of patch testing with lavender oil in Japan,"Contact Dermatitis. 2000;43(3):157-160.

63.Ernst E. "Herbal medicinal products during pregnancy: are they safe?" British Journal of Gynecology. 2002;109(3):227-235.

64.Perry R, Terry R, Watson L. K, Ernst E. Is lavender an anxiolytic drug? A systematic review of randomised clinical trials," Phytomedicine. 2012;19: 825-835.

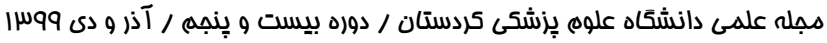

